\title{
Impact of ureteral access sheath force of insertion on ureteral trauma: In vivo preliminary study with 7 patients
}

\author{
(ㄷ) Tzevat Tefik, M.D., ${ }^{1,5}$ () Salvatore Buttice, ${ }^{2,5}$ M.D., (ㄷ) Bhaskar Somani, M.D., ${ }^{3,5}$ \\ Selçuk Erdem, M.D., ${ }^{1}$ (1) Tayfun Oktar, M.D., ${ }^{1}$ ¿ Faruk Özcan, M.D., ${ }^{1}$ \\ (1) Taner Koçak, M.D., ${ }^{1}$ () İsmet Nane, M.D., ${ }^{1}$ (1) Olivier Traxer, M.D. ${ }^{4,5}$
}

\begin{abstract}
1Department of Urology, İstanbul University İstanbul Faculty of Medicine, İstanbul-Turkey
${ }^{2}$ Department of Urology, San Giovanni di Dio Hospital, Contrada Consolida, Agrigento-Italy

${ }^{3}$ University Hospital Southampton NHS Trust, University of Southampton, Southampton-UK

${ }^{4}$ Sorbonne Université, GRC n²0 LITHIASE RENALE, AP-HP, Hôpital Tenon, Paris-France

${ }^{5}$ PetraUroGroup, Paris-France
\end{abstract}

\begin{abstract}
BACKGROUND: Ureteral access sheaths (UASs) are commonly used in retrograde intra-renal surgery (RIRS). Despite their advantages, there is a risk of ureteral trauma during their placement and subsequent stricture following surgery. The aim of this study was to evaluate the UAS force of insertion (FOI) during placement and its impact on ureteral trauma.
\end{abstract}

METHODS: Seven female patients who underwent RIRS for kidney stones were included in the study. A digital force gauge (Chatillon DFX II; Ametek Test and Calibration Instruments, Largo, Florida, USA) was connected to the distal end of the UAS and the UAS FOI was continuously measured during insertion. UASs of different sizes were used and ureteral injury was evaluated under direct vision with the Post-Ureteroscopic Lesion Scale (PULS) score.

RESULTS: Five pre-stented patients and 2 non-stented patients were included in the study. The size of the UASs used in non-stented patients was 9.5/I I.5-F and I0/I2-F, whereas one II/I3-F and four I2/I4-F sheaths were used in the pre-stented patients. The highest maximal UAS FOI observed was 5.9 Newton $(\mathrm{N})$ in a pre-stented patient with a I2/I4-F UAS, where a second attempt was performed after initial failure. The lowest maximal UAS FOI was $0.9 \mathrm{I} \mathrm{N}$ in a non-stented patient using a 9.5/I I.5-F UAS. A semirigid ureteroscopy with a 7.8-F sheath was performed in this patient prior UAS placement. The PULS score was I in the 2 non-stented patients and 0 in all of the pre-stented patients.

CONCLUSION: In this small cohort, a preoperative JJ stent seemed to protect the ureter, even with larger diameter UASs of I2/I4F. Non-stented RIRS with a UAS is possible, but may cause low-grade ureteral trauma.

Keywords: Force of insertion; retrograde intra-renal surgery; ureteral access sheath.

\section{INTRODUCTION}

Since their first introduction in 1974, ureteral access sheaths (UASs) have commonly been used to facilitate entry of ureteroscopes into the ureter. $^{[1]}$ Technological advancement led to a hydrophilic coating for UASs that decreased the shear force and made the passage smoother. ${ }^{[2]}$ This increase in safety resulted in wide use of UASs, especially during retrograde intra-renal surgery (RIRS) to treat kidney stones and upper tract urothelial carcinoma. UASs are now primarily used because they facilitate multiple passes of the ureteroscope into the renal collecting system and reduce intra-renal

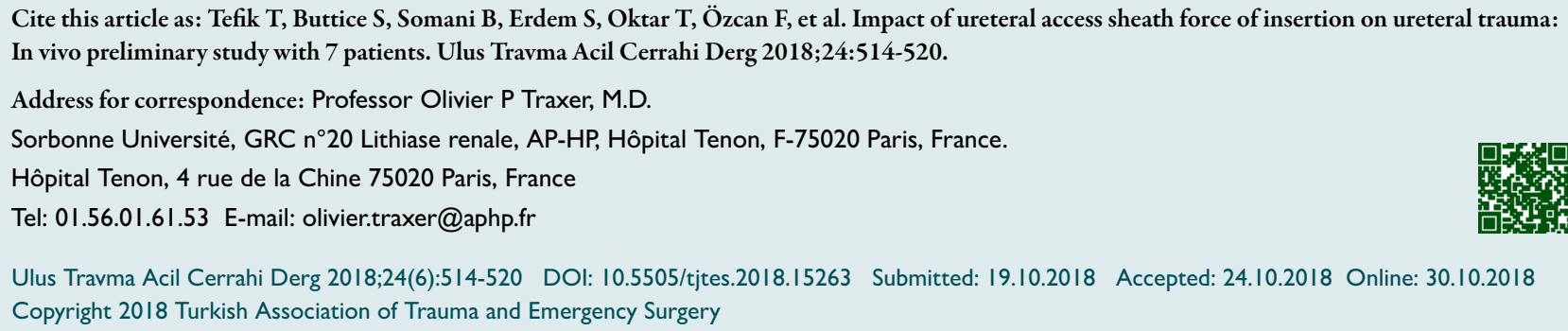


pressure by improving irrigation. ${ }^{[3,4]}$ Some authors have reported protection of endoscopes and others have claimed improvements in visibility with UAS use. ${ }^{[5,6]}$ Moreover it has been said to protect the ureter when extracting multiple stone fragments. ${ }^{[7]}$ Even though improvements in stone-free rates have been reported, there seems to be a lack of consensus on the topic. ${ }^{[8-10]}$

Despite their advantages, there are some important drawbacks to UAS use. They may decrease ureteral blood flow and induce long-term ureteral stricture formation. ${ }^{[1,12]}$ UAS usage also increases the overall cost of the procedure. ${ }^{[13]}$ As it is not positioned under direct vision, it may by-pass small stone fragments or tumors. ${ }^{[14]}$ Furthermore, UASs have the potential to damage the flexible scope if a small fragment becomes entrapped between the shaft of the scope and the inner wall of the UAS. ${ }^{[15]}$ Injury of the ureteral wall and severe ureteral trauma have been associated with excessive UAS insertion force. ${ }^{[16,17]}$ The aim of this preliminary study was to report the force of insertion (FOI) during placement of UAS and its impact on ureteral injury.

\section{MATERIALS AND METHODS}

\section{Patients}

A total of 7 patients who were to undergo therapeutic RIRS for kidney stones were recruited for this prospective cohort study. All of the patients were female and more than 18 years of age. Female patients were recruited for the cohort in order to avoid male urethral resistance in the UAS FOI measurements. The exclusion criteria were male gender, ureteral stricture disease, and use of medications for ureteral relaxation or anticoagulant treatment. All of the patients provided informed consent to undergo a RIRS procedure as per the principles of the Declaration of Helsinki consent process.

\section{Measurement of Ureteral Access Sheath Force of Insertion}

The distal part of the UAS was fixed to a load cell and the FOI was continuously recorded with a digital force gauge

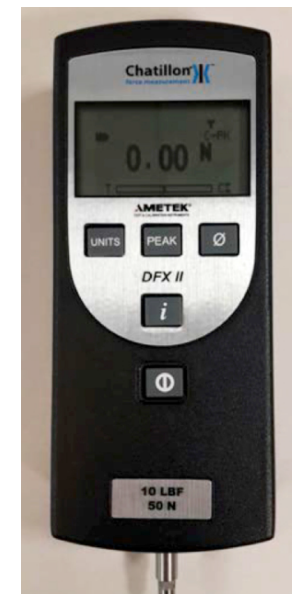

Figure 4. Digital force gauge (Chatillon DFX II; Ametek Test and Calibration Instruments, Largo, Florida, USA) used to measure force of insertion during placement.
(Chatillon DFX II; Ametek Test and Calibration Instruments, Largo, FL, USA) with the capability for readability from 0.0 I to 50 Newton $(\mathrm{N})$ at a millisecond frequency during placement (Fig. I). Specifically, one end of the load cell was fixed with $30^{\circ}$ to $35^{\circ}$ to the UAS proximal shaft. The other end of the load cell was held by the surgeon, where they would apply the necessary force for UAS placement to the load cell (Fig. 2). The load cell transmitted the pressure to the force gauge, continuously measuring and recording the FOI. All insertions were performed by a single surgeon (TT).

\section{Surgical Procedure}

All of the patients were placed in the lithotomy position under general anesthesia and the FOI was recorded by a single technician (ST). Each procedure began with the placement of two 0.035 -inch polytetrafluoroethylene-coated wires using a semi-rigid ureteroscope, I safety guidewire and I working guidewire in the renal pelvis. The orifice was marked using

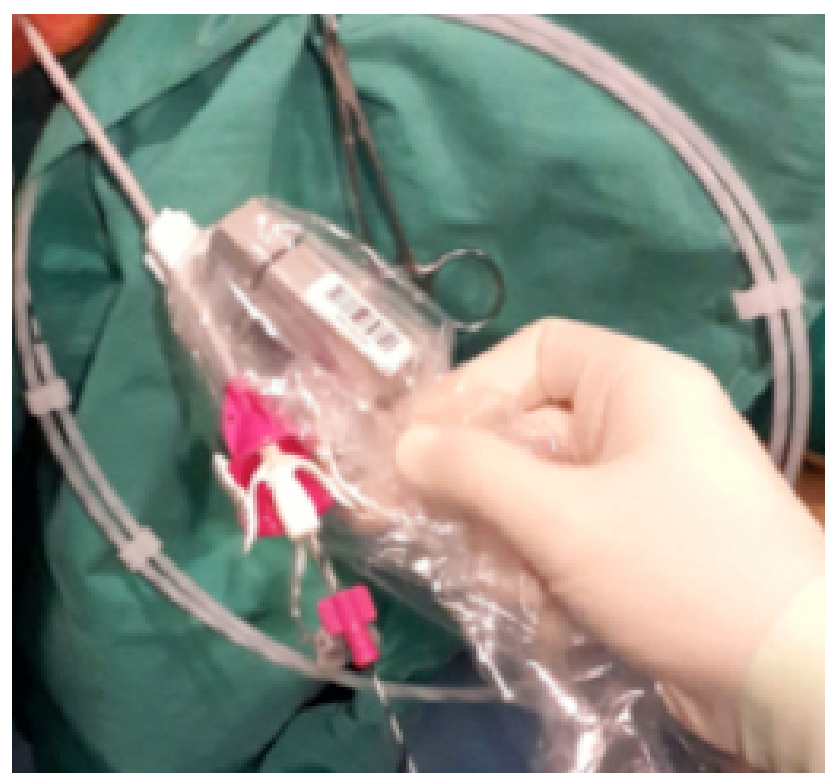

Figure 2. Insertion of a ureteral access sheath (UAS). One end of the load cell is fixed at a $30-35^{\circ}$ angle to the proximal shaft of the UAS. The surgeon holds the instrument on the other end of the load cell. The force of insertion from the surgeon's hand is applied directly to the load cell. The surgeon does not touch the UAS.

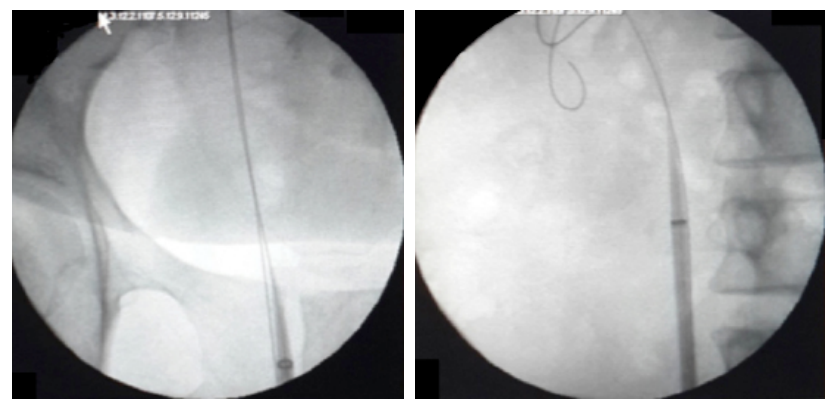

Figure 3. X-ray images during ureteral access sheath force of insertion measurement taken from the ureteral orifice until reaching the proximal ureter as confirmed with fluoroscopy. 
fluoroscopy. Then the tip of the inner dilator of the UAS was placed just at the ureteral orifice through the guidewire and confirmed with fluoroscopy. Subsequently, the load cell was fixed to the UAS. Recording was initiated at the ureteral orifice and continued until the placement of the UAS at the proximal ureter (Fig. 3). UASs of various sizes were used.

Following the surgery, the ureter was examined ureteroscopically after removing the UAS under direct vision. Ureteral injury was evaluated by the surgeon using Post-Ureteroscopic Lesion Scale (PULS) scoring. 18 A PULS grade 0 included mucosal contusions with minimal hematoma, grade I was a superficial tear of the mucosa, grade 2 was a deep tear of the mucosal and submucosal layers without contrast media extravasation, grade 3 was a localized perforation with contrast media extravasation, grade 4 was more than $50 \%$ transection of the ureter, and grade 5 was complete ureteric avulsion. ${ }^{[18]}$ $\mathrm{J}$ stents were placed in all patients and removed after I to 3 weeks. All of the patients underwent renal ultrasonography (kidneys, ureters, and bladder) to determine the presence of any residual fragments or hydronephrosis.

\section{RESULTS}

All of the RIRS operations were performed for kidney stones and were completed successfully. The median age of the patients was 46 years (interquartile range: 34-65 years). The stone location was in the lower calyx $(n=3)$, pelviureteric junction $(n=3)$, and the mid calyx $(n=1)$, with a mean stone size of $11.7 \pm 1.8 \mathrm{~mm}$. The median American Society of Anesthesiologists score was II. The patients' demographic data and stone characteristics are shown in Table I. Rocamed Bi-Flex (Rocamed, Monaco), Boston Scientific Navigator HD (Boston Scientific Corp., Marlborough, MA, USA), Cook Flexor (Cook Medical, Inc., Bloomington, IN, USA), and Olympus UroPass (Olympus Corp., Tokyo, Japan) were the 4 brands of UAS used. The UASs took an average of $9.9 \pm 2.6$ seconds to place with an average maximum FOI and load of $2.4 \pm 1.7 \mathrm{~N}$ and I. $2 \pm 0.6 \mathrm{~N}$, respectively. The UAS FOI and PULS scores are given in Table 2 .

Of the patients listed in Table I, patient $(\mathrm{Pt}) \mathrm{I}$ and $\mathrm{Pt} 7 \mathrm{had}$ no preoperative J stent (Table I). The maximum and aver-

Table I. Demographic data of patients and stone characteristics

\begin{tabular}{|c|c|c|c|c|c|c|c|}
\hline Patients & Age & Gender & Stone location & Stone size $(\mathrm{mm})$ & Laterality & Body mass index & ASA score \\
\hline I & 65 & Female & Ureteropelvic junction & 11 & Left & 35.9 & 4 \\
\hline 2 & 41 & Female & Middle calyx & 24 & Right & 28.9 & I \\
\hline 3 & 34 & Female & Upper calyx & 31 & Left & 23.4 & 1 \\
\hline 4 & 51 & Female & Lower calyx & 12 & Left & 36.3 & 3 \\
\hline 5 & 29 & Female & Lower calyx & 13 & Left & 29 & 1 \\
\hline 6 & 78 & Female & Ureteropelvic junction & 10 & Right & 32 & 4 \\
\hline 7 & 46 & Female & Lower calyx & II & Right & 31.2 & 2 \\
\hline
\end{tabular}

ASA: American Society of Anesthesiologists.

Table 2. Ureteral access sheath and force of insertion data of patients and ureteral lesion scores

\begin{tabular}{|c|c|c|c|c|c|c|c|c|c|c|}
\hline Patients & UAS brand & $\begin{array}{c}\text { UAS size } \\
\text { (F) }\end{array}$ & $\begin{array}{c}\text { Preop } \\
\text { JJ }\end{array}$ & $\begin{array}{c}\text { Preop } \\
\text { URS }\end{array}$ & Success & $\begin{array}{c}\text { Insertion } \\
\text { time } \\
\text { (sec) }\end{array}$ & $\begin{array}{l}\text { Max } \\
\text { load } \\
\text { (N) }\end{array}$ & $\begin{array}{l}\text { Average } \\
\text { load } \\
\text { (N) }\end{array}$ & $\begin{array}{l}\text { PULS } \\
\text { score }\end{array}$ & $\begin{array}{c}\text { Stone } \\
\text { free }\end{array}$ \\
\hline I & Rocamed $^{\circledR}$ Bi-Flex ${ }^{\mathrm{TM}}$ & $10 / 12$ & No & No & I. attempt & 15 & 1.9 & 1.88 & 1 & Yes \\
\hline \multirow[t]{2}{*}{2} & Boston Scientific & $11 / 13$ & Yes & No & I. attempt & 9 & 1.78 & 0.75 & 0 & No \\
\hline & Navigator ${ }^{\mathrm{TM}} \mathrm{HD}$ & & & & & & & & & \\
\hline 3 & Cook Flexor ${ }^{\circledR}$ & $12 / 14$ & Yes & No & I. attempt & 8.5 & 0.98 & 0.69 & 0 & No \\
\hline 4 & Cook Flexor ${ }^{\circledR}$ & $12 / 14$ & Yes & No & I. attempt & 11.5 & 2.11 & 0.75 & 0 & Yes \\
\hline 5 & Olympus UroPass ${ }^{\circledR}$ & $12 / 14$ & Yes & No & I. attempt & 10 & 3.02 & 1.56 & 0 & Yes \\
\hline 6 & Cook Flexor ${ }^{\circledast}$ & $12 / 14$ & Yes & No & I. attempt & - & 3.48 & 1.71 & 0 & Yes \\
\hline 6 & Cook Flexor ${ }^{\circledast}$ & $12 / 14$ & Yes & No & 2. attempt & 7 & 5.9 & 1.85 & 0 & Yes \\
\hline 7 & Cook Flexor ${ }^{\circledR}$ & $9.5 / 11.5$ & No & $7.8 \mathrm{~F}$ & I. attempt & 8.5 & 0.91 & 0.57 & 1 & No \\
\hline
\end{tabular}


age FOI with 10/I2-F UAS for Pt I was $1.9 \mathrm{~N}$ and $1.88 \mathrm{~N}$, respectively. Patient 7 had a narrow ureteric orifice and a rigid ureteroscopy with a 7.8-F ureteroscope was performed before inserting the UAS, thus passively dilating the ureter. After the ureteroscopy, the maximum and average $\mathrm{FOI}$ with 9.5/II.5-F UAS for Pt 7 was $0.91 \mathrm{~N}$ and $0.57 \mathrm{~N}$. respectively, (Fig. 4). A PULS score of I was observed in Pt 7.

The remaining 5 patients had JJ stents preoperatively. The gauge recorded no force after the ureterovesical junction (UVJ) until the beginning of the proximal ureter in Pt 2. Patient 3 had the lowest FOI among the pre-stented patients. with a maximum and average load of 0.98 and $0.69 \mathrm{~N}$, respectively. Patient 4's FOI graphic had demonstrative peaks at the ureteral narrow points (Fig. 5).

Pt 6, who was pre-stented, had 2 UAS insertion attempts. The first attempt was not successful, despite attempts at 3

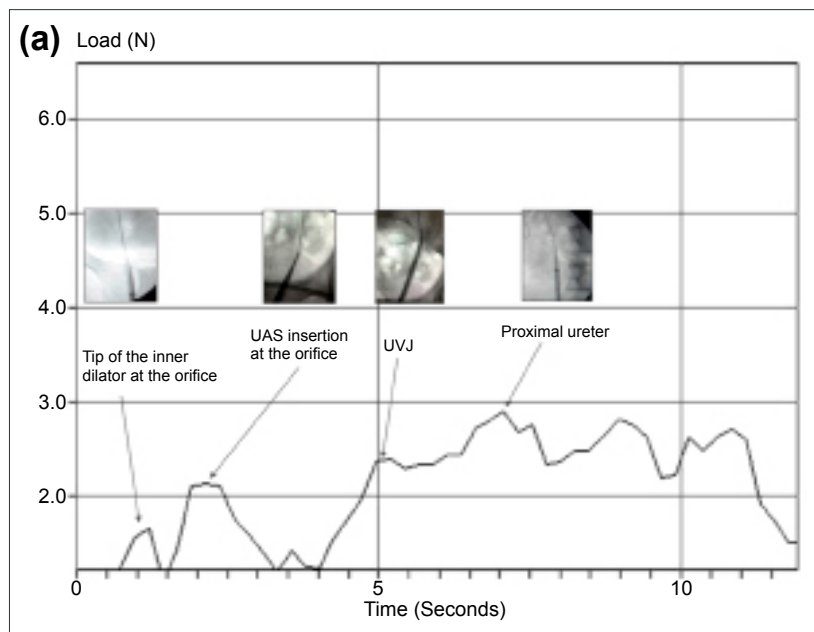

(b) $\operatorname{Load}(\mathrm{N})$

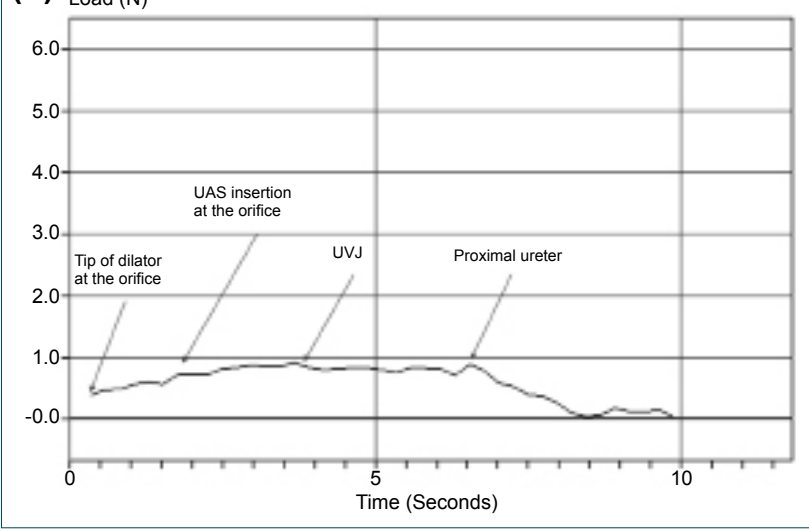

Figure 4. Force of insertion (FOI) graphs of patients without a preoperative JJ stent. (a) FOI of the 10/12-F Rocamed Bi-Flex (Rocamend, Monaco) ureteral access sheath (UAS) in Patient 1. The graphic demonstrates peaks at the entry of ureteral orifice, ureterovesical junction, and proximal ureter. (b) FOI of the 9.5/11.5F Cook Flexor UAS (Cook Medical, Inc., Bloomington, IN, USA) in Patient 7, who had undergone ureteroscopy prior to UAS insertion. Graphic without demonstrative peaks at the 3 ureteral narrow points. UAS: Ureteral access sheath; UVJ: Ureterovesical junction. consecutive force levels being applied in 3 seconds (Fig. 6a). The inner dilator of the UAS was in the distal ureter, but the sheath could not be inserted through the orifice. The UAS was pulled back and ultimately insertion was successful with a more forceful attempt. The FOI applied was doubled and there was a resistance of approximately $6 \mathrm{~N}$, which was relieved after passing through the orifice entrance. Figure $6 \mathrm{~b}$ demonstrates the pattern of peaks, a lower $\mathrm{FOl}$ at the $\mathrm{VUJ}$ and proximal ureter, compared with the orifice. A superficial bleeding tear at the intramural ureteral orifice was observed under direct vision at the close of the procedure.

\section{DISCUSSION}

Surgical management of kidney stones has changed dramatically in the last few decades. The wide use of RIRS has followed technological advancements in ureteroscopes, equipment, and flexible ureteroscopy techniques. ${ }^{\left[{ }^{[9]}\right]}$ Despite being controversial and a lack of overwhelming support, UAS is widely used in RIRS. ${ }^{[20]}$ The guidelines of the European Association of Urology have no clear recommendations for UAS usage, whereas the American Urological Association guidelines recommend the use of a UAS when performing RIRS for complex, high-volume renal stones. ${ }^{[2,22]}$ The natural ureteral

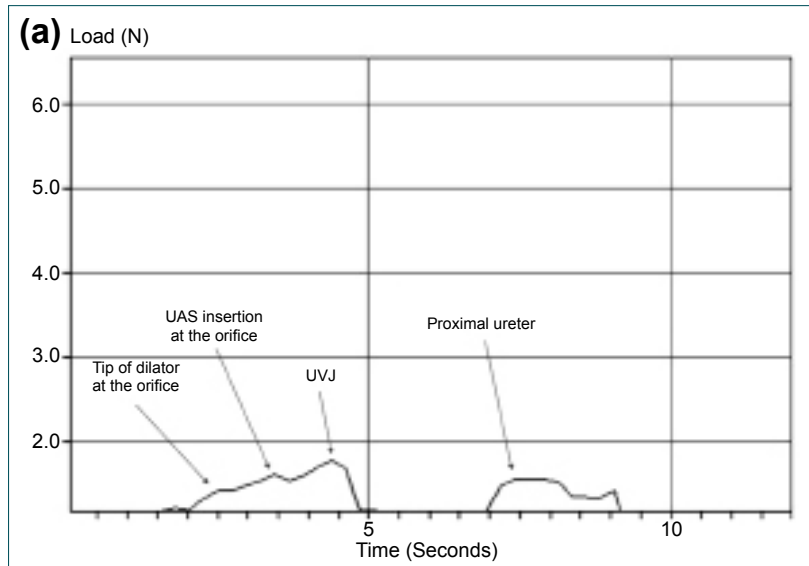

(b)

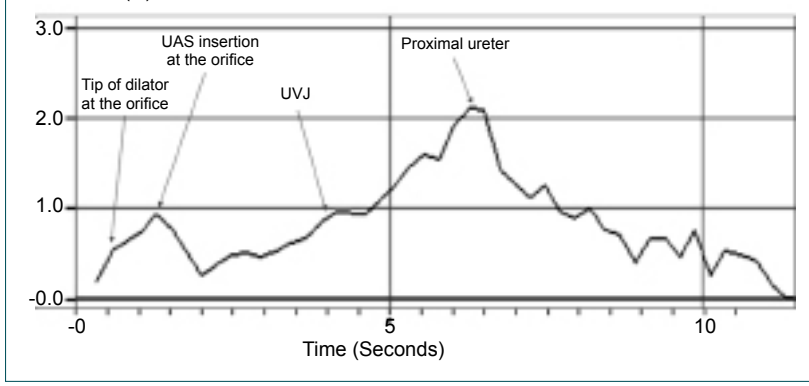

Figure 5. Force of insertion (FOI) graphs of patients with a preoperative JJ stent. (a) FOI of the 11/13-F Boston Scientific Navigator HD (Boston Scientific Corp., Marlborough, MA, USA) used in Patient 2. No force was recorded from the ureterovesical junction level to the beginning of the proximal ureter. (b) FOI of the 12/14 FCook Flexor sheath (Cook Medical, Inc., Bloomington, IN, USA) in Patient 4. FOI graph peaks are seen at the ureteral narrow points. UAS: Ureteral access sheath; UVJ: Ureterovesical junction. 


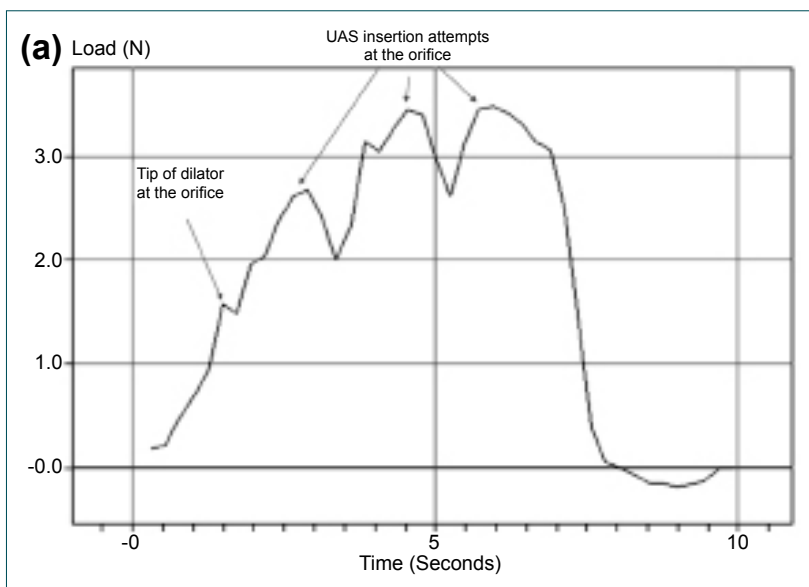

(b) Load (N)

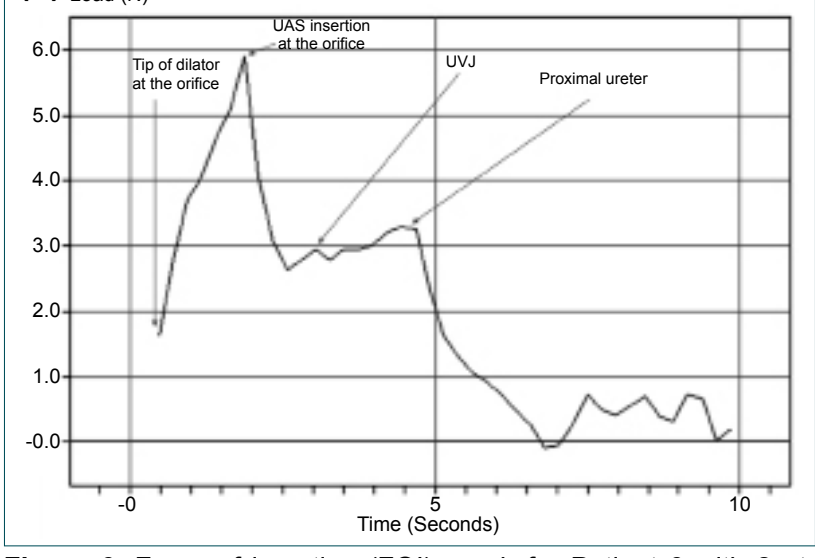

Figure 6. Force of insertion (FOI) graph for Patient 6 with 2 attempts made to achieve ureteral access sheath (UAS) insertion. (a) The unsuccessful first attempt to insert a 12/14-F Cook Flexor UAS (Cook Medical, Inc., Bloomington, IN, USA). The 3 peaks demonstrate the force applied 3 times at the ureteral orifice level without achieving passage of the UAS. (b) A different pattern of peaks of the same 12/14-F Cook Flexor UAS with less FOI at the ureterovesical junction and proximal ureter compared with the ureteral orifice site. Note that nearly double the force was applied on the second attempt in order to enter the ureteral orifice. UAS: Ureteral access sheath; UVJ: Ureterovesical junction.

lumen is 9-F, narrower than any UAS on the market. ${ }^{[23]}$ Insertion of a UAS dilates the ureteral wall, and thus has the risk of producing mucosal and submucosal edema, hematoma, and lesions. Applying disproportionate force may produce partial or even complete transection. The incidence of ureteral injury may be up to $46.5 \%$ when using a I2/I4-F UAS. ${ }^{[16]}$ Larger diameter UASs have a significant risk of causing mucosal ureteral injury, and this may not necessarily decrease with a smaller diameter sheath. Nevertheless, a smaller diameter appears to have a lower rate of causing deeper mucosal and smooth muscle lesions. ${ }^{[24,25]}$

Ureteral injury due to UAS placement does occur; however, there is no recommendation to abandon their use, due to the clear benefits they offer during RIRS. Traxer and Thomas ${ }^{[16]}$ reported a rate of $13 \%$ severe ureteral injuries with 12/14-F UAS. Male gender and older patients had a greater risk for severe ureteral injury. Severe smooth muscle layer lesions were described in lower rates (2.9\%) when using 9.5/II.5-F and I2/I4 F-UASs.24 Moreover, a I4/I6-F UAS had a higher rate $(17.6 \%)$ of deeper mucosal lesion with a reported rate of $4.7 \%$ circumferential perforation. ${ }^{[25]}$ Even though grade 3 ureteral injuries and full thickness separation of the ureter to the level of the periureteral fat have been described, ${ }^{[26]}$ in this preliminary report, we observed only superficial ureteral injuries in 2 patients with PULS scores of grade $\mathrm{I}$.

There are controversial reports regarding whether UAS increases the risk of ureteral stricture. Barbour and Raman ${ }^{[27]}$ reported a rate of $0.9 \%$ stricture following ureteroscopy with a UAS use rate of $22 \%$ in 234 patients. Baş et al. ${ }^{[28]}$ stated that they observed 2 strictures among $157 \mathrm{I}$ patients in their series. Another study found a $1.4 \%$ stricture rate following RIRS with the use of various sizes of UAS. Neither study concluded that UAS was a contributing factor to ureteral stricture. Similar conclusions were stated by Traxer et al, ${ }^{[10]}$ reporting no statistical significance regarding the use of UAS. We observed no ureteral stricture in this small cohort of patients.

A reduced ureteral blood flow with UAS placement does not seem to impact the ureter in the long-term. Lallas et al. ${ }^{\left[{ }^{1}\right]}$ demonstrated a decrease in blood flow in a swine model when UASs were used. The authors reported that the decrease in blood flow was more pronounced with a larger UAS and took longer to restore the ureteral blood flow; however, they concluded that it remains safe to use a UAS due to compensatory mechanisms of ureteral wall blood flow restoration to near-baseline rates, which preserved urothelial integrity. Since the 2002 report of Lallas et al., no study has clearly demonstrated a long-term impact of decreased blood flow in humans due to a UAS. It seems that, rather than transient ureteral ischemia, a direct mechanical injury has more impact on the ureter. In our study, we evaluated direct mechanical injury with the PULS scoring system.

Preoperative insertion of a J stent is a method used to facilitate UAS placement and to protect the ureter from UAS trauma. Passive dilatation was first reported by Jones et al. ${ }^{[29]}$ Shields et al. ${ }^{[30]}$ found significantly higher successful UAS insertion rates in pre-stented patients. Traxer and Thomas ${ }^{[16]}$ reported a 7-fold decrease in the risk of severe injury in prestented patients vs non-stented patients. Whereas, Doizi et al. ${ }^{[3 !]}$ found no difference in the success rate of UAS placement in pre-stented patients using new and innovative UAS. Koo et al. ${ }^{[32]}$ evaluated UAS FOI and found lower FOI values in pre-stented patients. In our study, we found lower UAS FOI values in pre-stented patients. We also noticed a PULS score of zero in all pre-stented patients and a PULS score of $\mathrm{I}$ in the non-stented patients.

Ureteral injury due to UAS seems not to be related simply to UAS diameter, but more to a mismatch in UAS and ureteral tone. One may assume that this tone could be felt by the 
surgeon as UAS FOI, and a higher FOI would mean a higher risk of ureteral injury. Koo et al. evaluated the UAS FOI in patients with an alpha-blockade, pre-stented patients, and controls. They found significantly lower and comparable UAS FOI values in the pre-stented and alpha-blockade patient groups. Additionally, they noticed higher UAS FOI values in males and patients less than 70 years of age. ${ }^{[32]}$ We did not administer an alpha-blockade to any of our patients and all of the patients in this study were female. Only Pt 6 was over 70 years of age and needed 2 attempts to achieve UAS placement. Even though pre-stented, Pt 6 had a higher UAS FOI compared to younger pre-stented patients. Progressive expansion in ureteral diameter and loss of the surrounding muscle mass with aging are believed to protect the ureter from UAS injury. [32] Notwithstanding, no ureteral injury was recorded in the pre-stented Pt 6 with a maximal UAS FOI of $5.9 \mathrm{~N}$.

Koo et al. also noted that ureteral injury (grade 2 injury, including mucosa and smooth muscle with adventitial preservation) did not occur in cases in which the UAS FOI was $<600$ $\mathrm{G}(600 \mathrm{G}=5.88 \mathrm{~N})$. Kaler et al. ${ }^{[33]}$ presented their study of a porcine model and reported no ureteral injury at UAS FOI $\leq 4 \mathrm{~N}$. They encountered ureteral injury (splitting of porcine ureter) at $8 \mathrm{~N}$. We had a PULS score of 0 in pre-stented patients with a maximum UAS FOI ranging from $0.98 \mathrm{~N}$ to $5.9 \mathrm{~N}$. There was a PULS score of I in non-stented patients with a maximum UAS FOI of $1.9 \mathrm{~N}$ and $0.9 \mathrm{I} \mathrm{N}$. It seems that even with a higher UAS FOI, the risk of ureteral injury is lower in pre-stented ureters. Conversely, even less UAS FOl may cause injury in non-stented patients. In Pt 7, a semirigid ureteroscopy was performed just before the UAS insertion. This facilitated the UAS placement and the insertion was done with a low force of $\max 0.9 \mathrm{I} \mathrm{N}$ and a steady graph without a feeling of resistance at the ureteral orifice. In this case, the semi-rigid ureteroscopy may have caused the PULS score I, so it may be misleading to comment on ureteral injury at a FOI of $0.91 \mathrm{~N}$.

This study has some drawbacks that merit mentioning. It is a small cohort study with only female patients, making it difficult to draw overall conclusions. However, this patient group helped to gauge only ureteral resistance, and excluded male urethral resistance. Male patients are associated with a greater risk of ureteral injury, mainly as a result of the difference in sex hormones and the surrounding muscle mass exerting higher tonic effect. ${ }^{[32,33]}$ Moreover, the size of the UASs used in this study were different, a factor making UAS FOI difficult to interpret. Lastly, the anesthetic drugs used were not taken into consideration. This may have influenced the results, as some anesthetics may have an effect on ureteral contractility and tone.

\section{Conclusion}

In this small cohort, pre-stenting patients before RIRS seemed to protect them from ureteral injury. A higher UAS FOI of
$<6 \mathrm{~N}$ in pre-stented compared to non-stented patients did not cause ureteral injury. A larger diameter UAS of I2-I4-F was safely used in pre-stented patients. Semi-rigid ureteroscopy before RIRS appeared to facilitate UAS placement. Using force gauge to measure UAS FOI may help future studies to better investigate successful and safe UAS placement.

\section{Conflict of interest: None declared.}

\section{REFERENCES}

1. Takayasu H, Aso Y. Recent development for pyeloureteroscopy: guide tube method for its introduction into the ureter. J Urol 1974;112:176-8.

2. Monga M, Bhayani S, Landman J, Conradie M, Sundaram CP, Clayman RV. Ureteral access for upper urinary tract disease: the access sheath. J Endourol 2001;15:831-4. [CrossRef]

3. Kourambas J, Byrne RR, Preminger GM. Does a ureteral access sheath facilitate ureteroscopy? J Urol 2001;165:789-93. [CrossRef]

4. Auge BK, Pietrow PK, Lallas CD, Raj GV, Santa-Cruz RW, Preminger GM. Ureteral access sheath provides protection against elevated renalpressures during routine flexible ureteroscopic stone manipulation. J Endourol 2004;18:33-6. [CrossRef]

5. Pietrow PK, Auge BK, Delvecchio FC, Silverstein AD, Weizer AZ, Albala DM, et al. Techniques to maximize flexible ureteroscope longevity. Urology 2002;60:784-8. [CrossRef]

6. Vanlangendonck R, Landman J. Ureteral access strategies: pro-access sheath. Urol Clin North Am 2004;31:71-81. [CrossRef]

7. De Coninck V, Keller EX, Rodríguez-Monsalve M, Audouin M, Doizi S, Traxer O. Systematic review of ureteral access sheaths: facts and myths. BJU Int 2018 May [Epub ahead of print], 11 doi: 10.1111/bju.14389.

8. Lesperance JO, Ekeruo WO, Scales CD Jr, Marguet CG, Springhart WP, Maloney ME, et al. Effect of ureteral access sheath on stone-free rates in patientsundergoing ureteroscopic management of renal calculi. Urology 2005;66:252-5. [CrossRef]

9. Portis AJ, Rygwall R, Holtz C, Pshon N, Laliberte M. Ureteroscopic laser lithotripsy for upper urinary tract calculi with active fragment extraction and computerized tomography followup. J Urol 2006;175:2129-33.

10. Traxer O, Wendt-Nordahl G, Sodha H, Rassweiler J, Meretyk S, Tefekli A, et al. Differences in renal stone treatment and outcomes for patientstreated either with or without the support of a ureteral access sheath: The Clinical Research Office of the Endourological SocietyUreteroscopy Global Study. World J Urol 2015;33:2137-44. [CrossRef]

11. Lallas CD, Auge BK, Raj GV, Santa-Cruz R, Madden JF, Preminger GM. Laser Doppler flowmetric determination of ureteral blood flow afterureteral access sheath placement. J Endourol 2002;16:583-90.

12. Delvecchio FC, Auge BK, Brizuela RM, Weizer AZ, Silverstein AD, Lallas $C D$, et al. Assessment of stricture formation with the ureteral access sheath. Urology 2003;61:518-22. [CrossRef]

13. Gurbuz C, Atış G, Arikan O, Efilioglu O, Yıldııım A, Danacıoglu O, et al. The cost analysis of flexible ureteroscopic lithotripsy in 302 cases. Urolithiasis 2014;42:155-8. [CrossRef]

14. Abrahams HM, Stoller ML. The argument against the routine use of ureteral access sheaths. Urol Clin North Am 2004;31:83-7. [CrossRef]

15. Kaplan AG, Lipkin ME, Scales CD Jr, Preminger GM. Use of ureteral access sheaths in ureteroscopy. Nat Rev Urol 2016;13:135-40. [CrossRef]

16. Traxer $\mathrm{O}$, Thomas A. Prospective evaluation and classification of ureteral wall injuriesresulting from insertion of a ureteral access sheath during retrogradeintrarenal surgery. J Urol 2013;189:580-4. [CrossRef] 
17. Lildal SK, Sørensen FB, Andreassen KH, Christiansen FE, Jung H, Pedersen MR, et al. Histopathological correlations to ureteral lesions visualized during ureteroscopy. World J Urol 2017;35:1489-96. [CrossRef]

18. Schoenthaler M, Buchholz N, Farin E, Ather H, Bach C, Bach T, et al. The Post-Ureteroscopic Lesion Scale (PULS): a multicenter video-based evaluation of inter-rater reliability. World J Urol 2014;32:1033-40.

19. Doizi S, Traxer O. Flexible ureteroscopy: technique, tips and tricks. Urolithiasis 2018;46:47-58. [CrossRef]

20. Huang J, Zhao Z, AlSmadi JK, Liang X, Zhong F, Zeng T, et al. Use of the ureteral access sheath during ureteroscopy: A systematic review and meta-analysis. PLoS One 2018;13:e0193600. [CrossRef]

21. Assimos D, Krambeck A, Miller NL, Monga M, Murad MH, Nelson CP, et al. Surgical Management of Stones: American Urological Association/ Endourological Society Guideline, PART I. J Urol 2016;196:1153-60.

22. Türk C, Petřík A, Sarica K, Seitz C, Skolarikos A, Straub M, et al. EAU Guidelines on Interventional Treatment for Urolithiasis. Eur Urol 2016;69:475-82. [CrossRef]

23. Zelenko N, Coll D, Rosenfeld AT, Smith RC. Normal ureter size on unenhanced helical CT. AJR Am J Roentgenol 2004;182:1039-41.

24. Guzelburc V, Guven S, Boz MY, Erkurt B, Soytas M, Altay B, et al. Intraoperative Evaluation of Ureteral Access Sheath-Related InjuriesUsing Post-Ureteroscopic Lesion Scale. J Laparoendosc Adv Surg Tech A 2016;26:23-6. [CrossRef]

25. Miernik A, Wilhelm K, Ardelt PU, Adams F, Kuehhas FE, Schoenthaler M. Standardized flexible ureteroscopic technique to improve stone-freerates. Urology 2012;80:1198-202. [CrossRef]

26. Patel RM, Okhunov Z, Kaler K, Clayman RV. Aftermath of Grade 3
Ureteral Injury from Passage of a UreteralAccess Sheath: Disaster or Deliverance? J Endourol Case Rep 2016;2:169-71. [CrossRef]

27. Barbour ML, Raman JD. Incidence and Predictors for Ipsilateral Hydronephrosis FollowingUreteroscopic Lithotripsy. Urology 2015;86:465-71. [CrossRef]

28. Baş O, Tuygun C, Dede O, Sarı S, Çakıcı MÇ, Öztürk U, et al. Factors affecting complication rates of retrograde flexible ureterorenoscopy: analysis of 1571 procedures-a single-center experience. World J Urol 2017;35:819-26. [CrossRef]

29. Jones BJ, Ryan PC, Lyons O, Grainger R, McDermott TE, Butler MR. Use of the double pigtail stent in stone retrieval followingunsuccessful ureteroscopy. Br J Urol 1990;66:254-6. [CrossRef]

30. Shields JM, Tunuguntla HS, Bhalani VK, Ayyathurai R, Bird VG. Construction-related differences seen in ureteral access sheaths: comparison of reinforced versus nonreinforced ureteral accesssheaths. Urology 2009;73:241-4. [CrossRef]

31. Doizi S, Knoll T, Scoffone CM, Breda A, Brehmer M, Liatsikos E, et al. First clinical evaluation of a new innovative ureteral access sheath( $\mathrm{Re}$ Trace $\left.^{\text {rut }}\right):$ a European study. World J Urol 2014;32:143-7. [CrossRef]

32. Koo KC, Yoon JH, Park NC, Lee HS, Ahn HK, Lee KS, et al. The Impact of Preoperative $\alpha$-Adrenergic Antagonists on UreteralAccess Sheath Insertion Force and the Upper Limit of Force Required to Avoid Ureteral Mucosal Injury: A Randomized Controlled Study. J Urol 2018;199:1622-30. [CrossRef]

33. Kaler K, O'Leary M, Valley Z, Cooper V, Yoon R, Patel R, et al. MP4.10: Initial clinical testing of ureteral access sheath force sensor to prevent ureteral injuries. Can Urol Assoc J 2018;12:S87.

\title{
ORIJINAL ÇALIŞMA - ÖZET
}

\section{Üreter erişim kılıfı yerleştirme sırasında sarfedilen gücün üreter travmasına etkisi: Yedi hastayla in vivo ön çalışma \\ Dr. Tzevat Tefik, ${ }^{1,5}$ Dr. Salvatore Buttice, ${ }^{2,5}$ Dr. Bhaskar Somani, ${ }^{3,5}$ Dr. Selçuk Erdem, ${ }^{1}$ Dr. Tayfun Oktar, Dr. Faruk Özcan, ${ }^{1}$ Dr. Taner Koçak, ${ }^{1}$ Dr. İsmet Nane, ${ }^{1}$ Dr. Olivier Traxer ${ }^{4,5}$}

\author{
1'stanbul Üniversitesi İstanbul Tıp Fakültesi, Üroloji Anabilim Dalı, İstanbul \\ ${ }^{2}$ San Giovanni di Dio Hastanesi, Üroloji Bölümü, Contrada Consolida, Agrigento-ïtalya \\ ${ }^{3}$ Southampton Üniversitesi, Southampton NHS Trust Üniversite Hastanesi, Southampton-Ingiltere \\ ${ }^{4}$ Sorbonne Université, GRC n²0 lıthıase renale, AP-HP, Hôpital Tenon, Paris-Fransa \\ ${ }^{5}$ PetraUroGroup, Paris-Fransa
}

AMAÇ: Erişim klıfları (EK) genellikle retrograt intrarenal cerrahide (RiRC) kullanılmaktadır. Avantajlarına rağmen yerleştirilmeleri sırasında üreter yaralanması ve cerrahi sonrasında darlık riski bulunmaktadır. Bu çalışmanın amacı sarf edilen itme gücünü ve üreter travmasına etkisini değerlendirmektir.

GEREÇ VE YÖNTEM: Böbrek taşları için RiRC uygulanmış yedi kadın hasta çalışmaya alındı. Bir dijital güç ölçüm cihazı (Chatillon DFX II; Ametek Test and Calibration Instruments, Largo, Florida, ABD) EK'ların ucuna monte edildi ve EK ile sarf edilen itme gücü, kıllfın yerleştirilmesi sırasında sürekli ölçüldü. Değişik boyutlarda EK'lar kullanıldı ve Postüreteroskopik Lezyon Ölçeği (PULS) skoru ile doğrudan görüş altında üreter yaralanması değerlendirildi.

BULGULAR: Daha önce stent konmuş beş ve konmamış iki hasta çalışmaya dahil edildi. EK’ların çapları daha önce stent konmamış hastalarda 9.5/II.5-F ve I0/I2-F, daha önce stent konmuş hastaların birinde II//3-F ve dördünde I2/I4-F idi. Daha önce stent konulmuş hastada I2/I4 F EK yerleştirmek için maksimal 9 Newton'luk $(N)$ itme gücü sarf edildiği gözlendi. Bu hastada ilk başarısız denemeden sonra ikinci kez deneme yapıldı. Bir stent konmamış hastada 9.5/ I I.5-F EK'ları yerleştirmek için en düşük maksimal EK itme gücü (0.9। N) sarf edildi. EK'yı yerleştirmeden önce bu hastaya 7.8-F semirijit üreteroskopi uygulanmıştı. İki stent konmamış hastada da PULS skoru I ve önceden stent takılmış hastaların tümünde 0 idi.

TARTIŞMA: Bu küçük çaplı kohort çalışmasında ameliyat öncesi JJ yerleştirilmesinin, üreteri I2/ I4F gibi geniş çaplı EK’ların travmasından koruduğu görülmüştür. Önceden stentsiz olan hastalarda RIRC uygulamasında EK yerleştirilmesi mümkün ise de bu durum düşük dereceli üreter travmasına neden olabilir.

Anahtar sözcükler: İtme gücü; retrograt intrarenal cerrahi; üreter erişim kllff.

Ulus Travma Acil Cerrahi Derg 20I8;24(6):5।4-520 doi: 10.5505/tjtes.20I8.I5263 